\title{
I nvestigation of Performance Task Studies Applied by Turkish Teachers for the Purpose of Consolidation and Evaluation
}

\begin{abstract}
Ali GÖÇER*
Received: 19 August 2013

Accepted: 21 January 2014

ABSTRACT: The aim of this study is to provide an overview of the applications of task performance as they are used to determine the status of the development in process and acquire the senior mental, linguistic, and social skills of students in secondary school Turkish lessons. In this study which adapted action research design in qualitative research approach, the data were obtained through interviews and document analysis method. The study was conducted on a study group consisting of 13 Turkish teachers. The data were obtained using the main form of the interview as a means of data collection. Additionally, were collected as examined document that products made by the task performance of students. The data were examined with content analysis method. According to the results of the data, almost all of the teachers in the study group have implemented performance tasks in accordance with the decisions of branch and the curriculum of the course.
\end{abstract}

Keywords: language training, performance task, determination of student achievement, assessment and evaluation.

\section{Extended Abstract}

Purpose and Significance: The aim of this study is to provide an overview of the applications of task performance as they are used to determine the status of the development in process and acquire the senior mental, linguistic, and social skills to the skills, students in secondary school Turkish lessons.

Performance task applications in schools are important in two respects: First, the performance task efforts are used to provide retention and reinforcement. Second, it is the tool used to determine the status of the students throughout the success of process. Second, it is used to determine the status of the students throughout the success of process.

Method: In this study which adapted action research design as a qualitative research approach, the data were obtained through interviews and document analysis method. Research was conducted on a working group consisting of 13 Turkish teachers who are working in the different provinces. The study group was established by selecting teachers who continuing education or has completed a master's degree in the field of Turkish education. The data were obtained using the main form of the interview as a means of data collection. Additionally, were collected as examined document that products made by the task performance of students and the minutes of the meetings of

\footnotetext{
** Assoc. Prof. Dr., Erciyes University Faculty of Education, Kayseri, Turkey, e-mail: gocer@erciyes.edu.tr; ali.gocer@hotmail.com
} 
the branch Turkish teachers working at the school. Descriptive statistical methods were used in the analysis of the personal information of the teachers. The data obtained from the interview questions and documents of products produced with the performance task by the students were examined with content analysis method.

Results: Almost all Turkish teachers giving 1 or 2 performance task in one educational period and believe that objectives and within the meaning of the studies was carried out with 1or 2 performance task.

Turkish teachers use student-centered alternative measurement and evaluation tools appropriate for the purpose and meaning at the evaluation of their performance tasks. According to the results from the data, almost all of the teachers in the study group have implemented performance tasks in accordance with the decisions branch and the curriculum of the course. Some of the Turkish teachers stated that performance task is an important tool in addition to being evaluation of student achievement and provides important contribution to the development of students' linguistic, cognitive and social skills.

Discussion and Conclusions: Turkish teachers consulted gives different performance tasks to improve students' linguistic, cognitive and social skills depending on the grade level. Turkish teachers took into consideration in determining of the performance tasks, and take the following variables into account: branch decisions, the acquisitions of learning and teaching process, the guide book recommendations, purposes of the program, environmental characteristics, level of student' interest and desire. Turkish teachers say that they give the different types and subject performance tasks. However, the documents collected from the students show that it is not the situation at all. Because, result of students' performance tasks were produced the preparation of the statement album, book summary extraction, preparation concept map on a subject of language etc. known materials. Turkish teachers state that they use the performance tasks to consolidate within the framework of an integral approach. In this way Turkish teachers created opportunities learning by doing and trying to develop high-level skills such as creativity, research, sense of responsibility, a sense of self-confidence, selfexpression, analysis-synthesis, interaction (effective communication). Turkish Teachers emphasize that performance tasks has important functions with this type of tasks in terms of contribution to students' cognitive, affective and social development.

As a result, performance task studies in schools both is an application area of students' cognitive, affective and social development as well as an assessment tool the students will learn about the development. Therefore the execution of the performance task studies should be move considering above-mentioned purpose and function. 


\title{
Türkçe Öğretmenlerinin Pekiştirme ve Değerlendirme Amacıyla Yürüttükleri Performans Görevi Çalışmalarının İncelenmesi
}

\begin{abstract}
Ali GÖÇER*
Makale Gönderme Tarihi: 19 Ağustos 2013

Makale Kabul Tarihi: 21 Ocak 2014

ÖZET: Bu araştırmanın amacı, ortaokul Türkçe derslerinde öğrencilere üst düzey zihinsel, dilsel ve sosyal beceriler kazandırmada ve öğrencilerin süreçteki gelişim durumlarını belirlemede kullanılan performans görevi uygulamalarının genel bir görünümünü sunmaktır. Nitel araştırma yaklaşımının eylem araştırması deseninde yürütülmüş olan bu araştırmada görüşme ve doküman inceleme yöntemleri kullanılmıştır. Araştırma, 13 Türkçe öğretmeninin oluşturduğu bir çalışma grubu üzerinden yürütülmüştür. Veriler, temel veri toplama arac1 olarak 5 sorudan oluşan görüşme formu kullanılarak elde edilmiştir. Ayrıca, öğrencilerin gerçekleştirdikleri performans görevi sonucu ortaya konulan ürünler de incelenecek doküman olarak toplanmıştır. Elde edilen veriler içerik analizi ile incelenmiştir. Elde edilen verilerden ulaşılan sonuçlara göre, çalışma grubundaki öğretmenlerin tamamına yakınının zümre kararları doğrultusunda ve ders müfredatının öngördüğü biçimde performans görevi çalışmalarını gerçekleştirdikleri görülmüştür.
\end{abstract}

Anahtar sözcükler: Dil eğitimi, performans görevi, öğrenci başarısının belirlenmesi, ölçme ve değerlendirme.

\section{Giriş}

Eğitim, bireylerin kendi yeteneklerinin farkına varıp, öz güven sahibi olmalarını ve sorumluluk bilincini kazanmalarını sağlayan dinamik bir süreçtir. $\mathrm{Bu}$ sürecin önemini bilen her öğretmenin çalışmalarını, öğrenciyi merkeze alarak düzenlemesi ve etkinliklerini davranış değişikliği amacıyla çeşitlendirmesi gerekmektedir. Öğrencilerin araştırarak ve keşfederek öğrenmelerine, yaparak-yaşayarak beceri kazanmalarına, öğrendiklerini arkadaşları, ailesi ve çevresindeki diğer insanlarla paylaşmalarına imkân tanımak, eğitimde istenilen davranış değişikliklerini oluşturmanın ilk ve en önemli adımıdır (Göçer, 2008). Öğrencilere bu niteliklerin kazandırılması birtakım farklı çalışmaları uygulamaya koymayı gerektirir. Bu çalışmaların başında öğretmenlerin süreç içinde ve süreç sonunda uyguladıkları öğrenci performans görevi çalışmaları gelmektedir.

Performans, öğrencinin edindiği bilgi ve becerileri kullanarak yeni bir ürünü ortaya koyarken gösterdiği çaba olarak tanımlanmaktadır. Bu bağlamda performans, öğrencilerin okul öğrenmelerini geliştirmek ve pekiştirmek amacıyla sınıf içinde ya da sınıf dışında bir etkinlik yaptıkları, bir ürün ortaya koydukları zaman oluşmaktadır (Kutlu, Doğan ve Karakaya, 2008). Performans değerlendirme, öğretim programındaki kazanımların edinim düzeyini belirler. Performans değerlendirmede performans, bir öğrencinin doğrudan veya dolaylı bir biçimde kalıcı bir üründe gözlenebilir bir cevabı aktif bir biçimde üretme anlamında kullanılabilir (Bahar, Nartgün, Durmuş ve Bıçak, 2006).

\footnotetext{
* Doç. Dr., Erciyes Üniversitesi Eğitim Fakültesi, Kayseri, Türkiye, e-mail: gocer@erciyes.edu.tr; ali.gocer@hotmail.com
} 
Öğrencinin sahip olduğu bilgi ve becerileri kullanarak günlük hayatla ilişkilendirilmiş bir ürün ortaya koymasına performans görevi denir. Performans görevleriyle öğrencilerden bir konuda araştırma yapmaları, araştırmalarını istenilen formatta hazırlamaları, verileri analiz etmeleri, yeni bir ürün ortaya koymaları veya birtakım bulguları yorumlamaları istenebilir. Performans görevleri, öğrencilerin birbirleriyle etkileşimde bulunmalarını sağlamak ve kendilerinin yaptığından emin olmak için sınıf ortamında da gerçekleştirilebilir. Performans görevleri kısa sürede tamamlanabilen, öğrenmeyi pekiştirme amaçlı kullanılan etkinliklerdir. Performans görevleriyle öğrencilerin öğrenmelerini faaliyete dönüştürmesi esastır (Başol, 2013).

Öğrenme ve öğretme sürecinde amaç ve kazanımları edindirmeye yönelik etkinliklerin gerçekleştirilmesi ve öğrencilerin dilsel, bilişsel ve sosyal açılardan üst düzey becerileri kazanmalarını sağlayabilecek ortamların oluşturulması öğretmenin donanımlı olmasıyla doğrudan ilişkilidir (Göçer, 2013). Performansa dayalı durum belirlemede öğrencilerin basit, yalın, alt düzey zihinsel düşünme gerektiren görevleri değil, daha üst düzey düşünme gerektiren karmaşık yapıdaki bazı görevleri yerine getirmeleri istenmektedir. $\mathrm{Bu}$ karmaşık görevler bir ürünün ortaya çıkarılmasını ve verilen bir problem durumuna çözüm önerileri getirilmesini içermektedir. Buradaki temel amaç öğrencinin yaratıcılık, problem çözme, eleştirel düşünme, karar verme, empati kurma gibi becerilerini ortaya çıkarmak, geliştirmek, bu yeteneklerin ne düzeyde geliştiğini ve kullanılabildiğini belirlemek ve öğrencinin bilgi düzeyinin ötesine geçerek yeni bilgiler üretmesini sağlamaktır (Kutlu vd., 2008). Öğretmenler hazırlamış oldukları ortamlarda öğrencileri merkeze alıp onlara yapacakları çalışmalarda rehberlik ederek yönlendirmede bulunurlar. $\mathrm{Bu}$ çerçevede öğrenciler, araştırma ödevleri, performans görevleri, proje çalışmaları gibi öğrencilerin üst düzey becerilerinin gelişmesine zemin olabilecek çalışma alanlarına yönlendirilmektedir. Etkinliklerin odağında olan öğrenciler de yapacakları çalışmalarla yeteneklerini sergilemeye, üstün bir performans ortaya koymaya çalışmaktadırlar.

Marzano, Pickering ve McTighe’ye (1993) göre, bireylerin belli bir konudaki bilgi, beceri ve anlama düzeyleri ile düşünme alışkanlıklarını yansıtmalarına imkân verebilecek farklı türden durumların/etkinliklerin oluşturulduğu değerlendirme türündeki çalışmalara performans değerlendirme denir (Aktaran: Birgin ve Küçük, 2012). Öğrenme ve öğretme sürecinde önemli olan öğrencilerin süreçte sergiledikleri çalışmalarda hedeflere yaklaşma ve kazanımlara ulaşma durumlarının nasıl olduğudur. $\mathrm{Bu}$ niteliğin belirlenmesinde farklı ölçme ve değerlendirme tekniklerinden yararlanılmaktadır. Öğretmenler öğrencilerin etkinliklere katılmalarını, araştırma ve inceleme çalışmalarına olan istekliliklerini ve süreç boyunca gösterdikleri değişme ve gelişme durumlarını belirlemede farklı araç ve yöntemler kullanmakta; bazı uygulamalar gerçekleştirmektedirler. Süreçte öğrenci performansını belirlemede başvurulan yollardan biri de performans görevi uygulamalarıdır. Birgin ve Küçük'e (2012) göre, performans değerlendirme belli bir amaca yönelik olarak öğrenciler tarafından tamamlanan ve belli performans ölçütlerine göre öğretmen ve öğrencinin kendi arkadaşlarınca değerlendirilen etkinlik ya da görevleri kapsar. 
Performans değerlendirme araç ve uygulamalarından biri de performans görevleridir. Kutlu ve arkadaşlarına (2008) göre, performans görevleri öğrencilere gerçek yaşamda karşılaşabilecekleri problem durumlarını sunan ve öğrencilerin üst düzey zihinsel becerilerinin geliştirilmesini ve ölçülmesini amaçlayan etkinliklerdir. Bu açıdan bir performans görevi; tanımlama, görev, yönerge ve puanlama yönetimi bölümlerinden oluşmaktadır. Tok’a göre, öğrenciler, öğrendikleriyle ilgili uygulama olanağı buldukça öğrendikleri pekişir ve kalıcı olur, gerçek yaşam problemleriyle baş edebilir. $\mathrm{Bu}$ nedenle öğrenciler kazanımlara, içeriğe, zamana, öğrenci özelliklerine uygun, sınıf içi ve dışı uygulama çalışmalarına yönlendirilmelidir (2007). Bu amaçla öğrencilere performans görevlerinin verilmesi ve onların bireysel çabalarının bir ürünü olarak sınıfta sunmaları için firsat tanınması gerekmektedir (Göçer, 2008). Bireysel ve grup çalışmalarıyla gerçekleştirilebilen, ürün kadar sürecin de göz önünde bulundurulmasına odaklanan performans değerlendirme, öğrencinin günlük yaşamındaki problemleri nasıl çözeceğini ve problem çözmek için sahip olduğu bilgi ve becerileri nasıl kullanacağını göstermesini ister (Bahar vd., 2006). Bir değerlendirme sürecinin performans dayanaklı olabilmesi için; ürün, gözlenebilir performans, üst düzey düşünme süreci, sosyal beceriler ve grup çalışması, disiplinler arası geçişin ve bilgi alışverişinin sağlanmış olması gerekir (Berberoğlu, 2006).

\section{Araştırmanın Amaç ve Kapsamı}

$\mathrm{Bu}$ araştırmanın amacı, ortaokul Türkçe derslerinde öğrencilere üst düzey zihinsel ve sosyal beceriler kazandırmada ve süreçteki gelişim durumlarını belirlemede kullanılan performans görevi uygulamalarının genel bir görünümünü sunmaktır. Bu amaç çerçevesinde aşağıdaki sorulara cevap aranmıştır.

1. Türkçe öğretmenlerinin performans görevlerini belirleme stratejileri nelerdir? Performans görevlerini hangi amaçla ve ne sıklıkta vermektedirler?

2. Türkçe öğretmenleri verdikleri performans görevlerinin takibi ve yürütülmesi konusunda nasıl bir yeterlik algısına sahiptirler?

3. Türkçe öğretmenlerinin verdikleri performans görevleri hangi konu ve alanlarda yoğunlaşmaktadır?

4. Türkçe öğretmenleri verdikleri performans görevlerinin değerlendirmesini nasıl yapmaktadırlar?

5. Türkçe öğretmenlerinin okullardaki performans görevi çalışmalarının işlevselliği; öğrencilerin bu çalışmalara katılımları, duygu ve düşünceleri konusundaki gözlem ve izlenimleri nelerdir?

\section{Yöntem}

\section{Araştırmanın Modeli}

Çalışma, nitel araştırma yaklaşımı çerçevesinde eylem araştırması olarak desenlenmiştir. $\mathrm{Bu}$ çerçevede görüşme ve doküman inceleme yöntemleri kullanılmıştır. Belirlenmiş uygulamaları içeren ve uygulayıcı öğretmenlerle etkileşimli ilerleyen bir 
süreç zarfında gerçekleştirilecek etkinliklerin biçimlendirilmesi ve uygulamadaki niteliğinin artırılması amacıyla bu araştırma deseni tercih edilmiştir.

Fraenkel ve Wallen (2003) eylem araştırmasını 'bir problemi çözmek ya da yerel bir uygulama hakkında bilgi vermek için bilgi toplamak amacıyla yapılan araştırma' olarak tanımlamaktadır (Aktaran: Kuzu, 2009). Eylem araştırması; nitel görüşme ve gözlemlerle toplanan verilerin kullanıldığı; araştırmacıların gerçekleştirilecek eylemlere ilişkin tartışma açıp, süreci izleyerek planlama, uygulama ve değerlendirmeler yaptı̆̆ı; yorumlama, yansıtma ve eylemden oluşan ve yansıtma aşamasında araştırmacıların veriyi yorumladığı, çoklu bakış açılarını paylaştığı bir süreci kapsar (Günel, 2012). Eylem araştırmasının planlama, harekete geçme (planı eyleme geçirme), gözlem yapma ve yansıtma (veri toplama, çözümleme ve yansıtma) şeklinde gerçekleşen döngüsel bir uygulama biçimi vardır (Köklü, 1993; Kuzu, 2009). Eğitimde aksiyon (eylem) araştırması 1980'li yıllardan başlayarak günümüze kadar yoğun olarak öğretmenlerin profesyonel gelişimlerini sağlamak amacıyla kullanılmaktadır. Bu araştırmayla beraber öğretmenlerin araştırmacı kimliği de ön plana çıkmakta ve sınıf içerisinde aktif olarak bilimsel bir çalışmanın merkezinde yer almaktadırlar (Ekiz, 2009; Ekiz, Erdoğan ve Uzuner, 2001).

\section{Çalışma Grubu ve Çalışma Dokümanı}

$\mathrm{Bu}$ araştırmanın çalışma grubunu, farklı illerde görev yapmakta olan 13 Türkçe öğretmeni oluşturmaktadır. Çalışma grubu oluşturulurken öğretmenlerin, yeni göreve başlamış ve alanında 'lisansüstü öğrenimi yapıyor veya tamamlamış olma'nın dikkate alındığı amaçlı örnekleme yöntemi tercih edilmiştir. Çalışma grubundaki tüm öğretmenlerle görüşmeler yapılmış, aynı zamanda gruptaki 4, 7, 9, 10, 11, 12 kodlu öğretmenler uygulayıcı öğretmen olarak seçilmiştir.

\section{Kişisel bilgiler}

Tablo 1'den de görülebileceği gibi araştırmaya 9'u kadın, 4'ü erkek olmak üzere toplam 13 öğretmen katılmıştır. Çalışma grubundaki öğretmenlerden 8’i yüksek lisansa devam etmekte; 2'si doktora, 3'ü de yüksek lisans derecesi sahibidir. Çalışma grubundaki öğretmenlerin 12'si 1-5 yıl; 1'i 6-10 yıl kıdem aralığındadır. Öğretmenlerin 11’i Eğitim Fakültesi Türkçe Öğretmenliği, 1’i Türk Dili ve Edebiyatı Öğretmenliği ve 1’i de Fen-Edebiyat Fakültesi Türk Dili ve Edebiyatı bölümünden mezun olmuştur. 
Tablo 1

Görüşme Yapılan Öğretmenlerle İlgili Kişisel Bilgiler

\begin{tabular}{lcc}
\hline Öğretmenlerin Cinsiyetlerine Göre Dă̆ılımı & $f$ & $\%$ \\
Kadın & 9 & 69.23 \\
Erkek & 4 & 30.77 \\
Toplam & 13 & 100.00 \\
\hline Mesleki Kıdem & $f$ & $\%$ \\
\hline $1-5$ yıl & 12 & 92.30 \\
6 yıl ve üzeri & 1 & 7.69 \\
Toplam & 13 & 100.00 \\
\hline Lisans Eğitimi Görülen Fakülte/Bölüm/Program & $f$ & $\%$ \\
\hline Eğitim Fakültesi Türkçe Öğretmenliği & 11 & 84.62 \\
Eğitim Fakültesi Türk Dili ve Edebiyatı Öğretmenliği & 1 & 7.69 \\
Fen-Edebiyat Fakültesi Türk Dili ve Edebiyatı & 1 & 7.69 \\
Toplam & 13 & 100.00 \\
\hline Yüksek Lisans / Doktora Eğitimi Alma Durumu & $f$ & $\%$ \\
\hline Lisans & 3 & 23.08 \\
Yüksek Lisans & 8 & 61.54 \\
Doktora & 2 & 15.38 \\
Toplam & 13 & 100.00 \\
\hline
\end{tabular}

\section{Verilerin Toplanması ve Analizi}

Eylem araştırmasını diğer araştırma desenlerinden ayıran en önemli özelliği, katılımcıları araştırma ekibinin bir parçası olarak araştırma sürecine doğrudan dâhil etme amacı bulunmasıdır. Katılım boyutu, dokümanları/araçları seçmeye, verileri toplamaya ve başlangıçtan bitişe kadar araştırmanın tüm yönlerine katılımı kapsamaktadır (Büyüköztürk, Çakmak, Akgün, Karadeniz ve Demirel, 2009). Çalışma grubu içerisinden 4 öğretmen uygulayıcı olarak seçilmiştir. 2012-2013 Öğretim yılı II. dönem başında seçilen öğretmenlerle görüşülerek çalışma hakkında bilgi verilmiş, materyal örnekleri derlenmesi istenmiştir. Veriler, dönem içinde öğretmenlerle yapılan görüşmelerle elde edilmiştir. Bunun yanında, Türkçe öğretmenlerinin yerleşim birimi/okul bazında dönem başında yapılan zümre toplantılarının tutanakları ile öğrencilerin dönem boyunca gerçekleştirdikleri performans görevi çalışmaları sonucunda ortaya konulan ürünler arasından seçilenler de doküman olarak incelenmiştir. Veri toplama aracı olarak 5 açı uçlu sorudan oluşan yarı yapılandırılmış görüşme formu hazırlanmıştır. Veri toplama aracı iki eğitim bilimcinin incelemesine sunulmuş ve uzman görüşü alınarak görüşme formuna son şekli verilmiştir. Görüşme formu ile ayrıntılı verilere ulaşılmaya ve öğretmenlerin algılarına ulaşarak elde edilen verilerin 
derinlemesine incelenmesine çalışılmıştır. Uygulamaların daha iyi yürütülmesi, yansıtılması ve süreç içerisinde yaygınlık kazanması için uygulayıcı öğretmenlerin gerçekleştirdiği çalışmalar arasından örnek ürünler seçilerek incelenmiştir.

Eylem araştırmasından elde edilen verilerin çözümlenmesinde en sık kullanılan yöntemler betimsel analiz, içerik analizi ve tümevarım analizidir (Kuzu, 2009). Bu araştırmada temel veri toplama aracı olan görüşme formu ile elde edilen veriler ile öğretmenlerin dönem boyunca öğrencilere verdiği performans görevi çalışma örneklerinin çözümlenmesinde içerik analizi yöntemi tercih edilmiştir. İçerik analizi, birbirine benzeyen verileri belli kavramlar ve temalar çerçevesinde bir araya getirmek ve bunları anlaşılabilir bir düzene sokarak yorumlamaktır (Yıldırım ve Şimşek, 2005). Nitel çözümlemede verilerin içeriklerini keşfetmeye yönelik çözümleme için kodlama ilk ve asli bir işlemdir (Punch, 2005). Veri analizi, verilerin düzenlenmesi, araştırma soruları çerçevesinde betimlenmesi ve yorumlanması aşamalarından oluşur (Yıldırım ve Şimşek, 2005). İçerik analizi yapılırken elde edilen verilerden hareketle kodlar oluşturulmuş; kodlardan yola çıkılarak temalara ulaşılmaya çalışılmıştır. Daha sonra elde edilen kod ve temalara göre yorumlamalar yapılmıştır. Öğretmenlere ait kişisel bilgilerin analizinde tanımlayıcı istatistiksel yöntem; dokümanlar ve görüşme formu verilerinin analizinde içerik analizi yöntemi kullanılmıştır. Araştırma etiği gereği uygulayıcı öğretmenlerin adları yerine kodlar kullanılmıştır.

Verilerin analizinde aşağıdaki işlem basamakları takip edilmiştir. İlk olarak öğretmenlerin görüşme sorularına verdikleri cevaplar bulgular bölümündeki tablolara işlenmiştir. Görüşme formu ve dokümanlarla elde edilen verilerin analizi işlemlerinde aşağıdaki kodlama ve tanımlama tekniği kullanılmıştır:

$\mathrm{A}_{1}, \mathrm{~A}_{2}, \mathrm{~A}_{3} \ldots$ : Araştırmacının sorularını,

Ö$_{1,2,3} \ldots$ : Görüşme yapılan katılımcıları (Türkçe öğretmenlerini),

UÖ$_{1}, 2, \quad 3 \ldots:$ Görüşme yapılan katılımcılar arasından seçilen uygulayıcıları (Uygulayıcı Türkçe öğretmenlerini),

$\left[{ }^{1}\right],\left[^{2}\right],\left[^{3}\right] \ldots$ : Katılımcıların kayda değer cevaplarından oluşan kelime, cümle ya da paragrafin numarasını göstermektedir.

$\mathrm{D}_{1,3,4 \ldots} / \ddot{\mathrm{O}}_{1,4,7 \ldots} ; \mathrm{D}_{2,3 \ldots} / \mathrm{O}_{2,4} / \mathrm{UÖ}_{7,9 \ldots}$ : İncelenmek üzere toplanan dokümanın numarasını/dokümanın sahibi olan öğretim elemanını göstermektedir.

\section{Bulgular}

\section{Görüşme Formları ile Elde Edilen Bulgular}

Görüşme sorularıyla elde edilen verilerin içerik analizi tablo 2'de verilmiştir. 


\section{Tablo 2}

Türkçe ögrretmenlerinin performans görevlerini verme sıklı̆̆ ile verdikleri performans görevlerinin takibi ve yürütülmesi ile ilgili görüşleri

$A_{1}$ : Bir dönem içerisinde ögrencilere kaç tane performans görevi veriyorsunuz? Verdiğiniz performans görevlerini süreç boyunca nasll takip ediyor, sürece yön verecek ne tür girişimlerde bulunuyorsunuz? Verdiğiniz performans görevi çalı̧̧maların amacina uygun olarak yürüttüğ̈̈nüzü düşünüyor musunuz, niçin?

Verilen performans görevi

$\ddot{\mathbf{O}}_{1,4,5,6,8, \mathbf{U}} \mathbf{U} \ddot{\mathbf{O}}_{9,11}$ : Bir dönem içerisinde 1 performans görevi veriyorum [ $\left.{ }^{1}\right]$. $\ddot{\mathbf{O}}_{6}$ : Bir dönem içerisinde 1 performans görevi veriyorum ancak dönem içinde performans adı altında olmadan da araştırma ödevleri veriyorum [ [ $\left.{ }^{2}\right] \ddot{\mathbf{O}}_{2,3,12} \mathbf{U} \ddot{O}_{7}$ : Bir dönem içerisinde 2 performans görevi veriyorum $\left[{ }^{3}\right]$. $\ddot{\mathbf{O}}_{13}$ : Bir dönem içerisinde 3 performans görevi veriyorum $\left[{ }^{4}\right]$. U $\ddot{O}_{10}$ : Bir dönem içerisinde 1veya 2 performans görevi veriyorum [ $[$ ].

\section{Performans görevi çalışmalarının takibi}

$\ddot{\mathbf{O}}_{1,2,3}, \mathbf{U} \ddot{O}_{4,9,11}$ : Haftanın belli günlerini görüşmeye ayırıp herkesle süreç içerisinde görüşmeye çalışıyor, bilgilendiriyor ve gereken yönlendirmelerle çalışmaları tamamlamaları için yardımcı oluyorum. Ancak her öğrenciyle tek tek ilgilenemiyorum. Ödevini yapmakta zorluk çektiğini düşündüğüm öğrencilere rehberlik yapıyorum. Gerekirse ödev konusunu değiştiriyorum [ $\left.{ }^{1}\right] . \ddot{O}_{5,6}$ ${ }_{12,13} \mathbf{U O ̈}_{7}$ : Öğrencilerden dönüt alıyor, yönlendirmelerde bulunuyorum. Ödevin zamanında teslimini de önemsiyorum $\left[^{2}\right]$. UÖ ${ }_{10}$ : Görev listesi hazırlıyor, öğrencilere performans görevi yönergesi ve değerlendirme ölçeğini dağıtıyorum. Zaman zaman görevle ilgili hatırlatmalarda bulunuyorum [ [3].

Performans görevi çalışmalarını yürütmeye yönelik yeterlik algısı

$\ddot{\mathbf{O}}_{\mathbf{1}, 2,3,5}, \mathbf{U} \ddot{O}_{9,10,11}$ : Evet, amaca uygun yürüttüğümü düşünüyorum, çünkü gereken yönergeleri verip takibini sağlıyor, kontrol ediyor ve yanlış ya da eksik anlaşılan yerlerde düzeltme yapıyorum [ $\left.{ }^{1}\right]$. $\ddot{\mathbf{O}}_{12}, \mathbf{U} \mathbf{O}_{4}$ : Evet, amaca uygun yürüttüğümü düşünüyorum. Verdiğim görevlerin amacina uygun olarak yürüttügü̈mü düşünüyorum. Öğrencilerde araştırma becerilerini geliştirmeye, sorumluluk alma becerisini geliştirmeye, okuma-anlama yönlerini geliştirmeye ve kendilerini daha iyi ifade etmeye yönelik görevler veriyorum. Öğrencilerde olumlu yönde ilerlemeler olduğunu gözlemlemekteyim []. $\ddot{O}_{6,8}$ : Aslında amacıma çok uygun yürütemiyorum. Çünkü köyde görev yaptı̆ı̆m için çocukların araştırma yapacakları ortam yok, öğrenci bu yüzden direkt internetten indirmektedirler $\left[{ }^{3}\right]$. UÖ$_{7}$ : Amacına göre yürütmeye çalışsam da öğrencilerin durumlarına göre esneklik gösterdiğim oluyor. Uygulama ya da yeni bir şeyler üretmeyi amaçlarken eğlenmelerini sağlamaya çalışıyorum $\left[^{4}\right]$. $\ddot{\mathbf{O}}_{13}$ :Performans görevi çalışmalarını amacına uygun olarak yürüttüğümü düşünüyorum. Çünkü dersler ile paralel olarak ve kazanımları pekiştirme amacı ile kullanıyorum [5].

\section{Kodlar Tema}

nicelik

açısından

performans

görevi

$\begin{array}{ll}\text { yönetme ve } & \\ \text { yönlendirme } & \text { Performans } \\ & \text { görevi } \\ & \text { çalışmaları } \\ & \text { ve } \\ & \text { öğretmenin } \\ & \text { yeterlik } \\ & \text { algısı }\end{array}$

yönerge

verme

Performans

kontrol ve görevlerinin düzeltme

takibi ve

İşlevselliği

eğlenerek

üretme 


\section{Verileri belirlenen tema ve kodlara göre tanımlama ve yorumlama}

Tablo 2'den de görülebileceği gibi Türkçe öğretmenlerinin yarıdan fazlası $\left(\ddot{\mathbf{O}}_{\mathbf{1 , 4 , 5 , 6 , 8}, \mathbf{U}} \mathbf{O}_{\mathbf{9}, 11}\right)$ bir dönemde 1; dört öğretmen $\left(\boldsymbol{\mathbf { O }}_{\mathbf{2 , 3 , 1 2}} \mathbf{U} \mathbf{O}_{7, \mathbf{1 0}}\right) 2$ ve bir öğretmen de 3 performans görevi vermektedir. Öğretmenler süreç boyunca yönergeler vererek yönetme ve yönlendirmelerde bulunmaktadır. Türkçe öğretmenlerinin tamamına yakını $\left(\ddot{\mathbf{O}}_{1,2,3,5,13} \mathbf{U O}_{4,9,10,11,12}\right)$ performans görevi çalışmalarını amaç ve anlamına uygun yürüttüklerini, 1 öğretmen (UÖ $\left.{ }_{7}\right)$ kısmen yürütebildiğini düşünmekte; iki öğretmen $\left(\ddot{O}_{6,8}\right)$ ise çevre şartları ve öğrenci algısı gibi sebeplerden dolayı amaca uygun yürütemediğini belirtmektedir.

\section{Tablo 3}

Türkçe ögretmenlerinin performans görevlerini belirleme stratejileriyle ilgili görüşleri

$\mathbf{A}_{2}$ : Öğrencilere vereceğiniz performans görevlerini belirlerken hangi stratejilerle hareket ediyorsunuz? Karar alma sürecine ögrencileri de katıyor musunuz? (Program, kllavuz kitap, zümre kararlarl, öğrenci Kodlar Tema özellikleri, ders kazanımları vb. unsurlar göz önünde bulundurularak)

$\ddot{O}_{1,2,13}$ : Zümre öğretmenimle konuşarak zümre kararlarımız doğrultusunda ve kılavuz kitaptaki önerilere göre iki üç değişik alternatif belirleyip sunuyor ve öğrencilerin seçmelerini sağlıyorum. Böylece sürece onları da katmış oluyorum [ $\left.{ }^{1}\right]$.

Ö$_{3}$ : Bu süreçte kılavuz kitabındaki öneriler, hangi sınıfta bulunduğu ve gelişim özelliklerini göz önünde bulundurarak görevler vermeye özen gösteriyorum $\left[^{2}\right]$.

Ö$_{5}, \mathbf{U O}_{4,10}$ : Dönem başında yaptığımız zümre toplantılarında belirlenen konulara ve program amaçlarına uygunluğuna göre geniş bir ödev listesi hazırllyorum. Daha sonra bu listeden öğrenci özelliklerini ve öğrencinin isteklerini dikkate alarak ödev konuları belirliyorum [ $\left.{ }^{3}\right]$.

Ö$_{6,12}$ : Genellikle kılavuz kitabımızı, dersin kazanımlarını, öğrenci ve çevre özelliklerini göz önünde bulunduruyorum. Karar alırken öğrencilere nadir soruyorum. Çünkü kendilerini kolay yoldan kurtaracak konulara yöneliyorlar [ $\left.{ }^{4}\right]$.

UÖ ${ }_{7}$ : Daha çok ders kazanımlarına göre vereceğim görevleri belirliyorum. Çeşitli görevlerden oluşan bir listeyi öğrencilerime veriyorum ve istediklerini kendileri seçiyorlar [ $\left.{ }^{5}\right]$.

Ö$_{8}$ : Zümre toplantılarında belirlenen konuları öğrenci özelliği, seviyesi ve ilgi alanına dikkat ederek veriyorum [ $\left.{ }^{6}\right]$.

UÖ ${ }_{9}$ : Performans görevlerini ilk dönem kılavuz kitap, program, zümre kararları ve ders kazanımları doğrultusunda veriyorum; II. dönem ise öğrenci istekleri ve özelliklerini doğrultusunda sunuma ve dramatizasyona yönelik oluyor $\left[{ }^{7}\right]$.

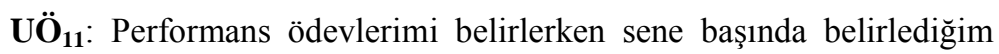
konuları içeren zümre tutanağını göz önünde tutuyorum. Ancak bu konuları belirlerken öğrencilerimle herhangi bir fikir alış verişinde bulunmuyorum $\left[{ }^{8}\right]$.

$\begin{array}{ll}\begin{array}{l}\text { zümre } \\ \text { kararları }\end{array} & \begin{array}{l}\text { Performans } \\ \text { görevi } \\ \text { çalışmaları }\end{array} \\ & \text { ve } \\ \text { kllavuz } & \text { planlanması } \\ \text { kitabı } & \text {. }\end{array}$

önerileri

program amaçlarına uygunluk

öğrenci

Hedeflerden haberdar nitelikleri ve ders kazanımları etme

$\begin{array}{ll}\begin{array}{l}\text { zümre } \\ \text { kararları }\end{array} & \begin{array}{l}\text { Hedef kitle } \\ \text { nitelikleri } \\ \text { ilgi, istek }\end{array} \\ \text { ve } & \text { Öğretmen } \\ \text { seviyesini } & \text { yaklaşımı } \\ \text { dikkate } & \text { ve } \\ \text { alma } & \text { uygulama- } \\ & \text { ları }\end{array}$




\section{Verileri belirlenen tema ve kodlara göre tanımlama ve yorumlama}

Elliot'a (1994) göre, seçilecek performans görevleri öğretilen konularla açık bir biçimde ilişkili olmal1; üzerinde çalışmaya başlamadan önce değerlendirme ölçütleri öğrencilerle paylaşılmalı ve öğrenciler ulaşılması hedeflenen standartlar ve kabul edilebilir performanslar hakkında açık bir biçimde bilgilendirilmelidir (Aktaran: Bahar vd., 2006). Tablo 3 'ten de görülebileceği gibi Türkçe öğretmenleri; zümre kararları, ders kazanımları, kılavuz kitabı önerileri, program amaçları, öğrenci seviyesi, ilgi ve istekleri ile çevre özelliklerini göz önünde bulundurarak performans görevlerini belirlemektedirler. Öğretmenlerin tamamına yakını belirlenen görevlerin verilmesinden sonra öğrencilerde görev bilinci oluşturmak için hedeflerden haberdar etmekte ve süreç içerisinde gerekli rehberliği yapmaktadırlar.

Tablo 4

Türkçe ögretmenlerinin verdikleri performans görevlerinin hangi konu ve alanlarda yoğunlaştı̆̆ına dair görüşleri

$\boldsymbol{A}_{3}$ : Verdiğiniz performans görevlerine birer ikişer örnek verebilir $\quad$ Kodlar $\quad$ Tema
misiniz?

Ö: 5. sınıf: 'Deyim albümü hazırlıyoruz.' 6. sınıf: Atatürk'ün hayatından anıları derleyerek bir kitap oluşturma. 7. sınıf: Atatürk'ün hayatını anlatan bir anıyı grup oluşturarak canlandırma. 8. sınıf: Çevre kirliliği hakkında neler yapılabilir? Kendinizi belediye başkanının yerine koyarak çözüm önerisi üretiniz? [1].

dramatizasyon

empati

becerisi

$\ddot{O}_{2}$ : 5. smıf: İstediğiniz bir yazarın romanını okuyarak sınıfta sunumunu yapınız? 6. sınıf: Noktalama işaretlerini anlatan bir hikâye oluşturunuz? 7. sınıf: Okulumuzu tanıtacak bir afiş hazırlama. 8. sınıf: Türk destanlarından birini seçerek grup olarak sinifta tanitiniz. [ [ $]$.

$\ddot{O}_{3}:$ 5. sınıf: Gördükleri dil bilgisi konusuyla ilgili resimli kavram haritası oluşturma, okudukları hikâyenin hikâye haritasının renkli fon kartlarına hazırlama, bilmecelerle ilgili oyun hazırlama. 6. sınıf: Fıkra yazıp canlandırma Karagöz-Hacivat oyunu canlandırma. 7. sınıf: Haber sunma, gazetedeki herhangi bir olayla ilgili sınıfta tartışma ortamı hazırlayıp görüş alış verişinde bulunma. 8. sınıf: Okul gazetesi hazırlama, çocuk dergisi hazırlama, şiir dinletisi hazırlama... [ [3].

U $\ddot{O}_{4}:$ 5. sınıf: Karagöz ve Hacivat oyunu (Tiplemelerin ve sahnenin yapılışı-sergilenmesi). 6. sınıf: Çevrede görülen tabelalardaki dil yazma becerisi

$\begin{array}{ll}\text { gazete, dergi, } & \text { Performans } \\ \text { görevlerinin } \\ \text { şir dinletisi } & \text { öğrenci } \\ & \text { gelişiminde- } \\ & \text { ki önemi ve } \\ & \text { işlevleri }\end{array}$
hatalarını bulma. 7. sınıf: Drama, skeç canlandırma. 8. sınıf: Bir hikâye yazma. [4].

Ö ${ }_{5}$ : 5. sınıf: Yaratıcı fabl yazma. 6. sınıf: Drama çalışmaları. 7. sınıf: Fiillerle ilgili poster hazırlama. 8. sınıf: Şiir dinletisi, türkülerin çıkış kaynaklarını araştırma [5].

dil bilgisel çalışmalar 
Tablo 4'ün devamı

\begin{tabular}{|c|c|c|}
\hline & Kodlar & Tema \\
\hline $\begin{array}{l}\ddot{\text { O}}_{6} \text { : 5. sınıf: Masal derleme ve birini anlatma. 6. sınıf: Hikâye } \\
\text { derleme ve birini anlatma. 7. sınıf: Bir şairin hayatını anlatma ve } \\
\text { bir şiirini ezberleme. 8. sınıf: Bir kitabı okuyup tahlil etme }\left[{ }^{6}\right] \text {. } \\
\text { UÖ }{ }_{7} \text { : 5. sınıf: Atatürk'ün anılarını derleme. 6. sınıf: Deyim albümü } \\
\text { hazırlama, metin türleri afişleri hazırlama. 7. sınıf: Türkçenin doğru } \\
\text { kullanımıyla ilgili uyarı levhaları hazırlama, Atatürk'e ait } \\
\text { özdeyişleri derleme. 8. sınıf: Vatan şiirleri antolojisi hazırlama, } \\
\text { noktalama işaretleri afişi hazırlama [7]. }\end{array}$ & $\begin{array}{l}\text { araştırma } \\
\text { becerisi } \\
\text { değerlerimiz }\end{array}$ & \multirow{5}{*}{$\begin{array}{l}\text { Üst düzey } \\
\text { dilsel, } \\
\text { zihinsel, } \\
\text { duyuşsal ve } \\
\text { sosyal } \\
\text { becerilerin } \\
\text { gelişimi }\end{array}$} \\
\hline $\begin{array}{l}\text { Ög: 5. sınıf: Yaratıcı masal yazma. 6. sınıf: Hikâye yazma, şair } \\
\text { veya yazarların hayatlarının edebi yönlerinin araştırılması, roman } \\
\text { özetleme. 7. sınıf: Deyimlerin ve atasözlerinin çıkış noktalarının } \\
\text { araştırılması, işlenilen temaya uygun pano hazırlama. 8. sınıf: } \\
\text { Roman yazma, şiir defteri oluşturma, sınıf dergisi hazırlama [8]. } \\
\text { UÖg: 6. sınıf: Fon müziği eşliğinde ezbere şiir okuma, mektup } \\
\text { yazma, hikâye yazıp resimleme, seçme şiir defteri oluşturma, anı } \\
\text { canlandırma. 7. sınıf: Fon müziği eşliğinde ezbere şiir okuma, } \\
\text { mektup yazma, eser inceleme (seviyeye uygun romanlar), seçme } \\
\text { şiir defteri oluşturma. 8. sınıf: Eser inceleme (seviyeye uygun } \\
\text { romanlar), Fon müziği eşliğinde ezbere şiir okuma, seçme şiir } \\
\text { defteri oluşturma, dilbilgisi konuları ile ilgili tablolar hazırlama. }\left[^{9}\right] \text {. }\end{array}$ & $\begin{array}{l}\text { seçme şiir } \\
\text { defteri } \\
\text { oluşturma }\end{array}$ & \\
\hline $\begin{array}{l}\text { UÖ }{ }_{10} \text { : 6. sınıf: Verilen metin içerisinde istenen ses olaylarının } \\
\text { bulunması, verilen } 5 \text { kelime kullanılarak masal yazılması, şiir } \\
\text { yazılması, karikatür çizilmesi. 7. sınıf: Atasözleri ve deyimleri } \\
\text { oyunlaştırma, şair ve yazarlar afişi hazırlama. 8. sınıf: Düşünceyi } \\
\text { geliştirme yolları ve anlatım biçimlerine birer örnek paragraf yazma } \\
\left.{ }^{10}\right] \text {. }\end{array}$ & $\begin{array}{l}\text { şair ve } \\
\text { yazarlar afişis }\end{array}$ & \\
\hline $\begin{array}{l}\text { Ü̈ }{ }_{11} \text { : 5. sınıf: Atık maddelerden hayalindeki evi oluşturma. } 6 . \\
\text { sınıf: TRT Çocuk'ta yayımlanan "Keloğlan Masalları" isimli çizgi } \\
\text { filme hayalen bir bölüm yazma. 7. sınıf: Atasözleri, deyim ve } \\
\text { vecize kutusu oluşturma. 8. sınıf: Ünlü Türk edebiyatçılarının } \\
\text { hayatını araştırma [11]. }\end{array}$ & hazırlama & \\
\hline $\begin{array}{l}\text { Ö}_{12} \text { 5. sınıf: Güzel ülkem Türkiye temasında başta Karadeniz'deki } \\
\text { iller olmak üzere il il tanıtım broşürleri hazırlama, kitap okuma } \\
\text { saatlerindeki okuma performansları ve diğer görevlendirmeler }\left[{ }^{12}\right] \text {. } \\
\text { Ö}_{13} \text { : 5. sınıf: Seçilen mesleği tanıtan bir rapor, dergi, sunu, poster } \\
\text { veya broşür hazırlama. 6. sınıf: Yirmi gün süreli günlük tutma. } 7 \text {. } \\
\text { sınıf: "Bilim adamı", "sporcu", "ses sanatçısı", "film/tiyatro } \\
\text { sanatçısı" ve "şair/yazar" olarak ün yapmış kişilerden birer kişi } \\
\left.\text { seçerek toplam beş ünlünün hayatlarını araştırma [ }{ }^{13}\right] \text {. }\end{array}$ & $\begin{array}{l}\text { Poster ve } \\
\text { broşür } \\
\text { hazırlama }\end{array}$ & \\
\hline
\end{tabular}

Verileri belirlenen tema ve kodlara göre tanımlama ve yorumlama

Tablo 4'ten de görülebileceği gibi, Türkçe öğretmenleri performans görevlerinin öğrencinin gelişiminde önemi ve işlevlerini göz önünde bulundurarak her sınıf düzeyinde öğrencilerin üst düzey dilsel, zihinsel ve sosyal becerilerin geliştirilmesine yönelik farklı tür ve konuda performans görevleri vermektedirler. Öğretmenler 
verdikleri performans görevleriyle ilgili olarak beşinci sınıfta 11, altıncı sınıfta 12, yedinci sınıfta 12 ve sekizinci sınıfta 11 ayrı tür ve konuda performans görevi örneği belirtmişlerdir.

\section{Tablo 5}

Türkçe öğretmenlerinin verdikleri performans görevlerini nasıl değerlendirdiklerine dair görüşleri

$\mathbf{A}_{4}$ : Verdiğiniz performans görevlerinin değerlendirmesini nasıl yapıyorsunuz? Süreç başında değerlendirme ölçütleri konusunda ögrencileri bilgilendiriyor ve onlar değerlendirme sürecine katıyor musunuz? (İрucu: öz, akran, grup değerlendirme

Kodlar

Tema tekniklerinden ögrencileri bilgilendirip onlarl kullanıyor musunuz?)

$\ddot{O}_{1}$ : Süreç başında dereceli puanlama anahtarı oluşturuyorum. Öğrencilerime de hangi bölüme ne kadar puan vereceğim konusunda gereken bilgilendirmeleri yapıyorum. Öz ve akran değerlendirme uygulamasını sınıflar kalabalık olduğu için uygulayamiyorum $\left[{ }^{1}\right]$.

$\ddot{O}_{2}$ : Performans görevlerini önceden belirlediğim kriterlere göre değerlendiriyorum. Öz değerlendirme formu kullanıyorum $\left[{ }^{2}\right]$.

$\ddot{O}_{3}$ : K1lavuz kitaptaki gözlem formlarından yararlanıyorum ve değerlendirme ölçütleri ile ilgili formları öğrencilere veriyorum, böylece süreçte ölçütleri göz önünde bulundurarak çalışmalarına yön veriyorlar. Görevleri sergiledikten sonra öz değerlendirme ve akran değerlendirme formlarını dağıtıp değerlendirme sürecinde onların da aktif katılmalarını sağlıyorum [ $\left.{ }^{3}\right]$.

U $\ddot{O}_{4,9}, \ddot{O}_{13}$ : Süreç başında değerlendirme ölçeğini sınıf panosuna asıyorum. Ödev konularına göre öz değerlendirme, grup değerlendirmesi gibi teknikleri öğrencilere bildiriyorum. Öğrencinin araştırma sürecine katılımına; raporun teslim tarihine; yazım-noktalama kurallarına uyum ve sunum gibi ölçütlerine dikkat ediyorum $\left[{ }^{4}\right]$.

$\ddot{\mathbf{O}}_{5, \mathbf{8}, \mathbf{U}} \mathbf{U}_{4, \mathbf{1 0}}$ : Performans görevlerini verirken ona uygun rubrik de öğrencilere dağıtıllyor. Öz değerlendirme, grup değerlendirme, akran değerlendirme gibi diğer değerlendirme teknikleri kılavuz kitapta yer verildiği gibi yapıllyor [ [ $]$.

$\ddot{O}_{6}$ : Performans değerlendirme ölçeği hazırlıyorum. Nelere dikkat etmeleri gerektiğini onlarla paylaşıyorum. Öz değerlendirme yapıyorum $\left[{ }^{6}\right]$.

UÖ ${ }_{11}$ : Performans derecelendirme ölçeği hazırlıyorum. Öğrenciler daha sürecin başında hangi noktalardan ne kadar puan alacağını biliyor ve ödevini ona göre hazırlıyor [ [ ] .

$\ddot{\mathbf{O}}_{12}$ : Performans görevini yapanlar sinıfa sunum hazırlarlar ve hep beraber dinler değerlendirmemizi yaparız $\left[{ }^{8}\right]$.

dereceli

puanlama

anahtarl

oluşturma

öz

değerlendirme

gözlem

formlart

değerlendirme

ölçütleri

öz, akran ve

grup

değerlendirme

değerlendirme

içeriği ve

kapsamı

rubrikler

öz ve grup

değerlendirme

değerlendirme

ölçütleri

hakkında bilgi

verme

değerlendirme

için

hazırbulunuş-

luk 


\section{Verileri belirlenen tema ve kodlara göre tanımlama ve yorumlama}

Türkçe öğretmenlerinin tamamı verilecek performans görevlerinin değerlendirmesinde kullanılacak ölçütler konusunda öğrencileri süreç başında bilgilendirmektedirler (bk. Tablo 5, $\left[^{1,2,3,4,5,6,7}\right]$ ). Öğretmenler öğrencilerin performans görevlerinin değerlendirmesinde gözlem formları, öz değerlendirme, grup değerlendirme, akran değerlendirme araç ve yöntemlerini kullandıklarını belirtmişlerdir (bk. Tablo 5, [1,2,3,4,5,6]). Performans görevlerinin değerlendirilmesinde 5 öğretmen $\left(\ddot{O}_{1,5,8}, \mathrm{UO}_{4,10}\right)$ amaca en iyi hizmet edecek olan dereceli puanlama anahtarı (rubrik) oluşturarak değerlendirme yaptığını belirtiştir. Bu uygulama çok olumlu bir nitelik olarak değerlendirilebilir. Çünkü 6, 7 ve 8. Sınıflar Türkçe Programında verilen 'Performans görevlerinin değerlendirilmesinde özellikle dereceli puanlama anahtarları kullanılmaktadır' (MEB, 2006) şeklindeki açıklamaya bire bir uyan bir uygulamadır. Dereceli puanlamalı ölçeklerde temel prensip değerlendirilecek boyutların tanımlanmış olması ve her boyutun hangi niteliklere göre değerlendirileceğinin belirlenmesidir (Berberoğlu, 2006). Araştırmada görüşüne başvurulan diğer öğretmenler de cevaplarında 'dereceli puanlama anahtarı (rubrik)' kullanıyorum demeseler de yapılan çalışmaların değerlendirmesini görev dağıtımı öncesi belirlenen ölçütlere göre aşama aşama yaptıkları anlaşılmaktadırlar (bk. Tablo 5, Ö${ }_{2,3,6,9,11,12,13} \mathrm{UÖ}_{4,9}$ ). Öğretmenler, öğrencilerin çalışmalarını değerlendirirlerken performans hazırlama süreci, performansın içeriği ve sunu yapma bölümlerinden oluşan performans değerlendirme ölçeği kullanmaktadır. Tablo 5'te öğretmenlerin verdikleri cevaplarda da anlaşılabileceği gibi, Türkçe öğretmenleri amaca hizmet eden ölçme ve değerlendirme araçları kullanmaktadırlar.

\section{Tablo 6}

Türkçe ögrretmenlerinin okullardaki performans görevi çalışmalarının işlevselliği ile ögrencilerin bu çalışmalara katılımlarına yönelik gözlem ve izlenimleri nelerdir?

$\boldsymbol{A}_{5}$ : Okullarda yapılan performans görevlerinin işlevselliğ $i$ konusunda ne düşünüyorsunuz? Verdiğiniz performans görevleri sonunda öğrencilerin duygu ve düşünceleri konusunda gözlem ve izlenimleriniz hakkında bilgi verebilir Kodlar Tema misiniz?

Performans görevi çalışmalarının işlevselliği

Ö$_{1}$ : Performans görevi özellikle sınıflar kalabalık olduğu zaman uygulamak takip etmek noktasında çok sıkıntı yaşanıyor. Bir de özel ilgi gerektiren öğrencilerimizin sayısı da fazla olduğu zaman süreç oldukça zorlaşıyor. Bunun dışında performans görevinin çok şey kattığını düşünüyorum $\left[{ }^{1}\right]$. Ö${ }_{2}$ : Öz yeterlilik duygularını geliştirmesi açısından işlevsel olduğunu düşünüyorum $\left[{ }^{2}\right]$. Ö ${ }_{3,5}$ : Performans görevleri öğrencilerin her zaman çok hoşuna gidiyor. Hem öğrenme gerçekleştirmekte hem de eğlenerek, yaparak-yaşayarak öğrendikleri için işlevsel olduğunu düşünüyorum $\left[{ }^{3}\right]$. perf. görevi uygulamalarl ve takibi

Öğrenci

kazanımlart açısından perf. görevleri

\section{Performans} görevi çalışmalarının işlevselliği 
Tablo 6'nın devamı

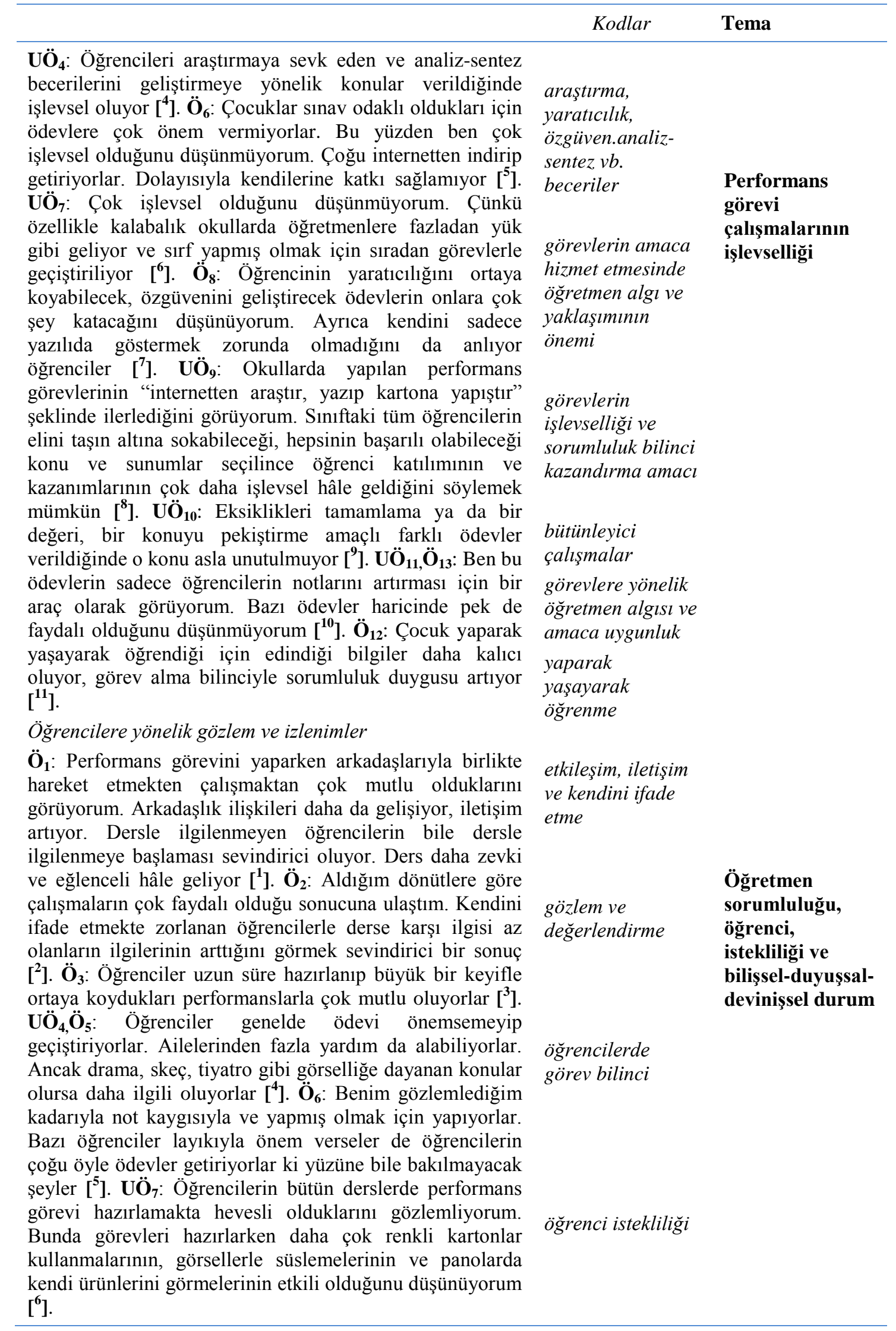


Tablo 6'nın devamı

\begin{tabular}{|c|c|c|}
\hline & Kodlar & Tema \\
\hline 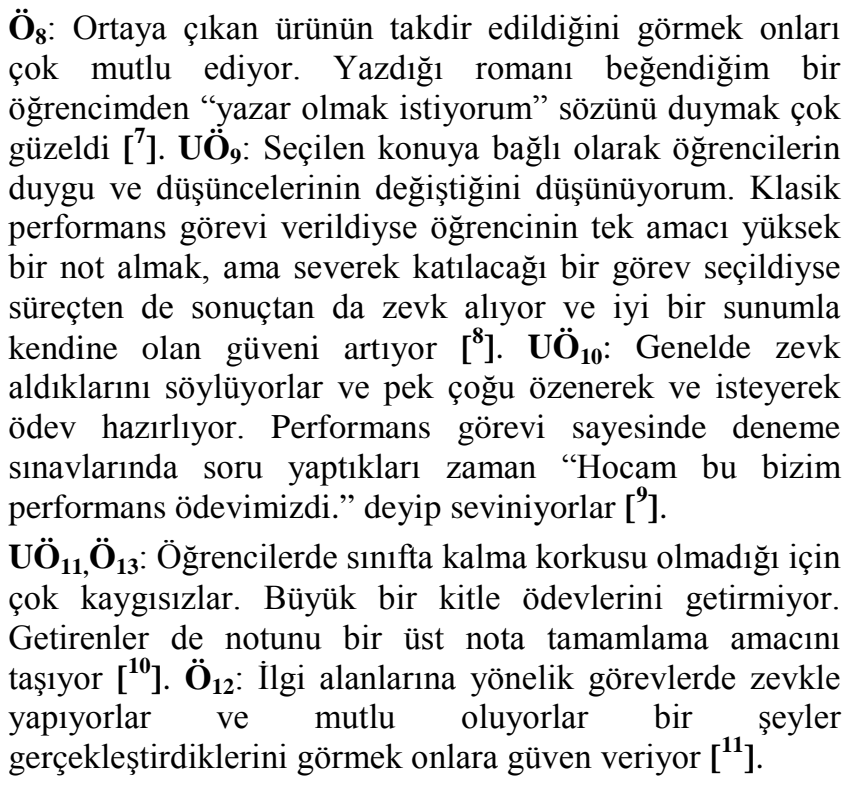 & $\begin{array}{l}\text { ögrenci ürünlerine } \\
\text { yönelik } \\
\text { geri bildirim ve } \\
\text { pekiştireç } \\
\text { kullanma } \\
\text { ögrenci } \\
\text { motivasyonu ve } \\
\text { görev bilinci }\end{array}$ & $\begin{array}{l}\text { Öğretmen } \\
\text { sorumluluğu, } \\
\text { öğrenci, } \\
\text { istekliliği ve } \\
\text { bilişsel-duyuşsal- } \\
\text { devinişsel durum }\end{array}$ \\
\hline
\end{tabular}

\section{Verileri belirlenen tema ve kodlara göre tanımlama ve yorumlama}

Performans görevleri, öğrencilerin üst düzey zihinsel becerilerini ortaya koyabilecekleri yapıda, anlaşılır, ilgi çekici ve sınıf düzeyine uygun olmalıdır. Yönergesi öğrenciye rehberlik edecek şekilde açık ve net olmalıdır (Kutlu vd., 2008). Performans görevleri birkaç günde yapılabileceği gibi birkaç hafta da sürebilir. Bu nedenle öğrencilere, sınav saatleriyle sınırlandırılmaksızın geniş bir zaman diliminde çalışma ve tekrar etme, oluşturulan ölçütlere göre yeterlik derecelerini ortaya koyma imkânı verir. Öğrencilerin gerçek performanslarını ölçmek açısından uygun araçlardır (MEB, 2006).

Performans görevleri gerek öğrencilerin performans görevine yönelik alg1, istek, amaç ve beklentileri gerekse uygulamaların takibi, geri bildirim, pekiştireç kullanma, amaca uygunluk vb. öğretmen yaklaşımları açısından önemli işlevlere sahiptir. Katılımcılardan alınan cevaplarına bakıldığında öğrencilerin not tamamlama amacıyla yaklaşmaları veya not tamamlama aracı olarak görmeleri dışında performans görevlerinin olumlu işlevleri vurgulanmıştır.

Görüşüne başvurulan Türkçe öğretmenlerinin öğrencilerin bu çalışmalara katılımlarına yönelik gözlem ve izlenimlerine bakıldığında performans görevlerinin bütünleyici çalışma çerçevesinde yaparak yaşayarak öğrenmelerle araştırma, yaratıcılık, sorumluluk bilinci, özgüven duygusu, kendini ifade etme, analiz-sentez, etkileşim (etkili iletişim) vb. becerilerin gelişmesine zemin olması ve öğrenci kazanımları açısından önemli olduğu belirtilmektedir. Yine Türkçe öğretmenleri okullardaki performans 
görevi çalışmalarının öğrencilerin bilişsel, duyuşsal ve sosyal gelişimlerine katkısı açısından önemli işlevlere sahip olduğunu vurgulamışlardır.

Dokümanların (öğretmenlerin gerçekleştirdiği performans görevleri arasından örnek olarak seçilen ürünler) İncelenmesiyle Elde Edilen Bulgular

Fotoğraflar 1. Öğretmenlerin Performans Görevi Olarak Verdiği Çalışmalara Bir Örnek: Deyimler Sözlüğü (Kapak ve Bir İç Sayfa: D 1-2 $_{\text {UÖ }}$ Ö$_{13}$ )
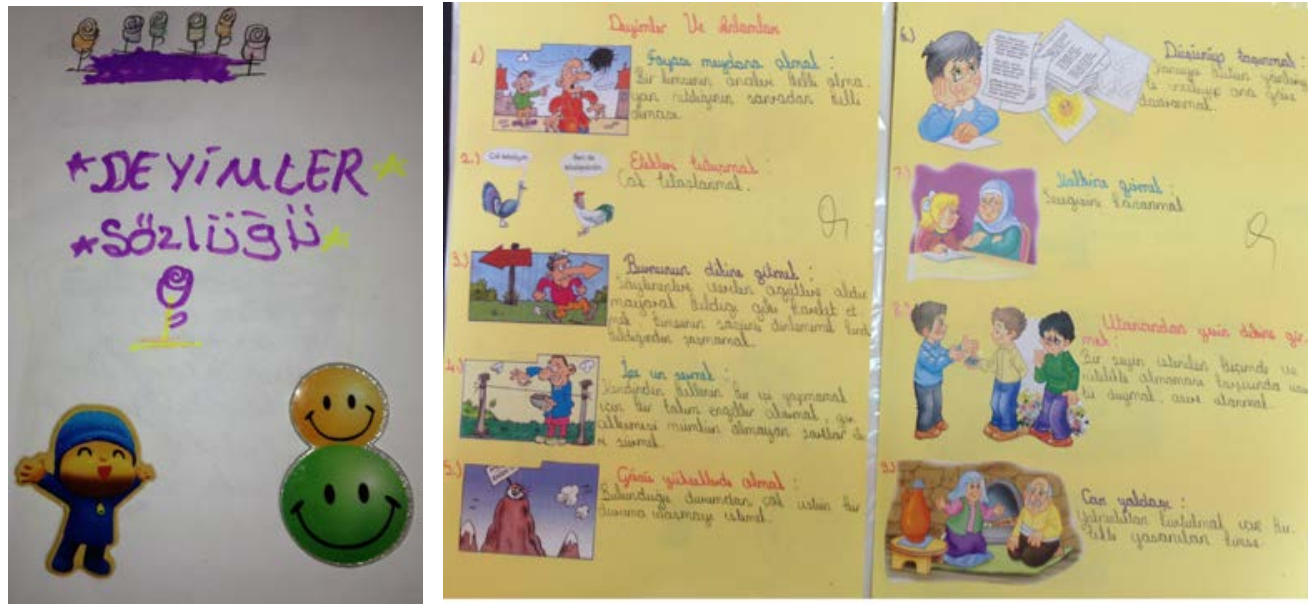

Fotoğraflar 2. Dil Bilgisi Öğrene Alanında Bireysel ve Grup Olarak Yürütülen Performans Görevi Ürünleri ( $\left.\mathrm{D}_{3,4,5,6,7,8} / \mathrm{UÖ}_{4,7,9,10,11} \mathrm{O}_{13}\right)$
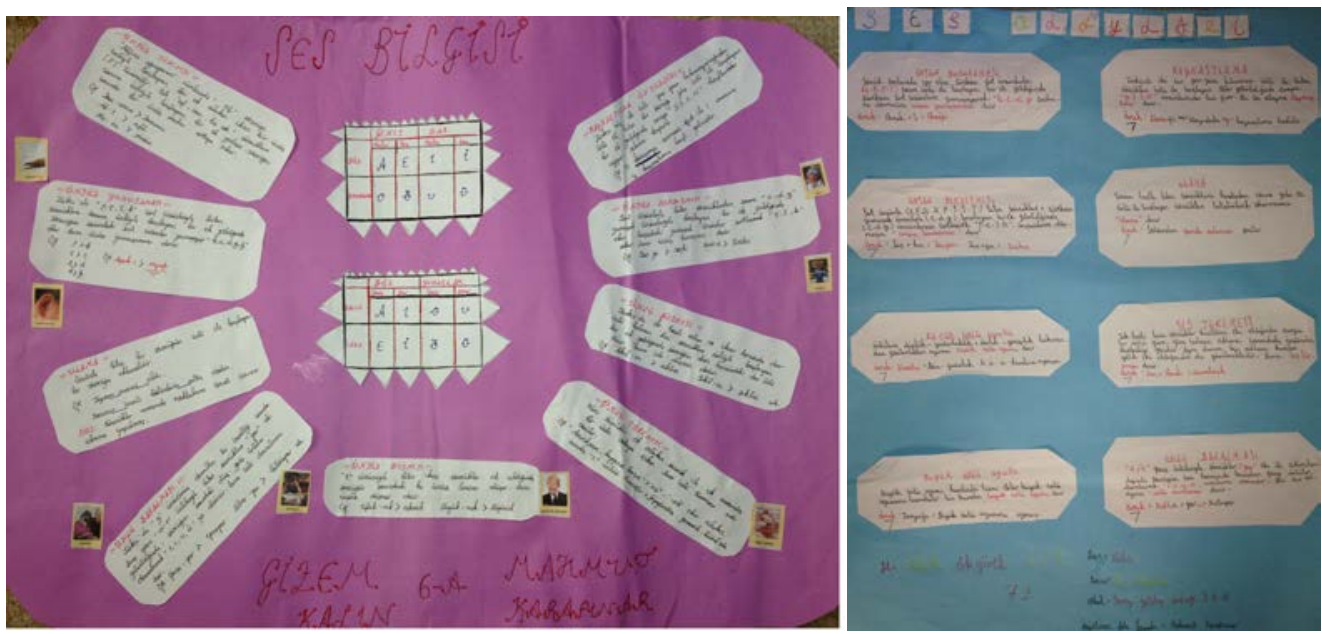
Fotoğraflar 2'nin devamı
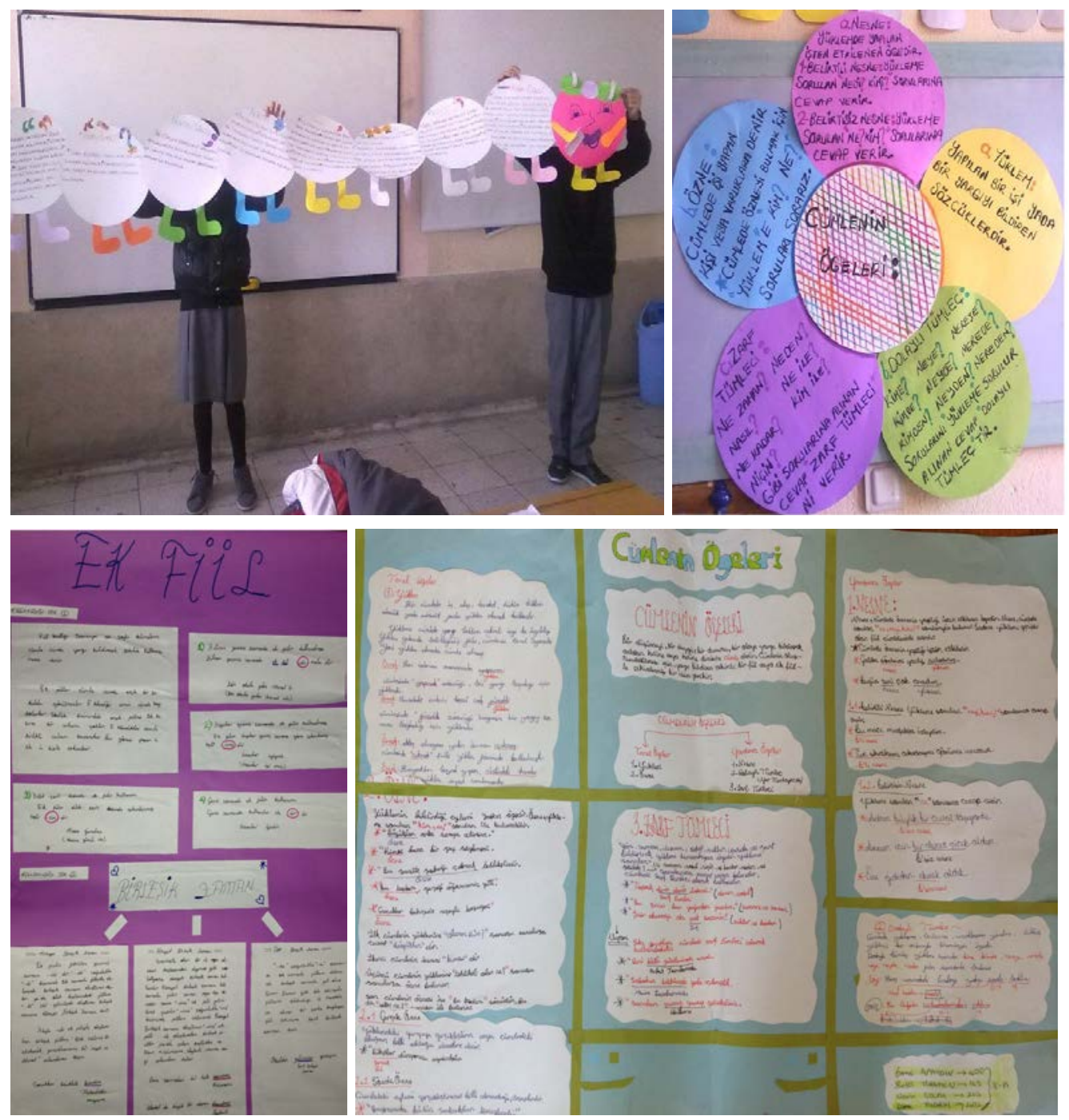

Fotoğraflar 3. Yazılı Anlatım Becerisiyle İlgili Performans Görevi Ürünleri $\left(\mathrm{D}_{9,10,11,12} / \mathrm{UÖ}_{9,10,11} \ddot{\mathrm{O}}_{13}\right)$
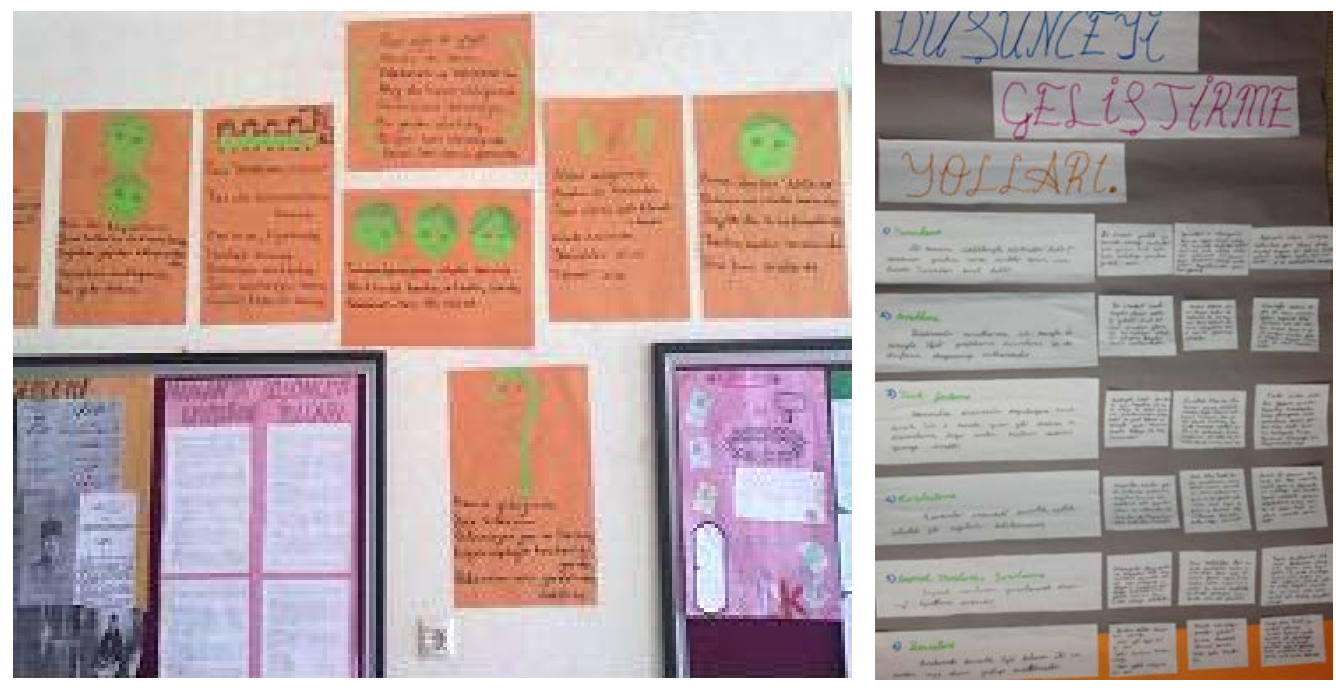
Fotoğraflar 3'ün devamı
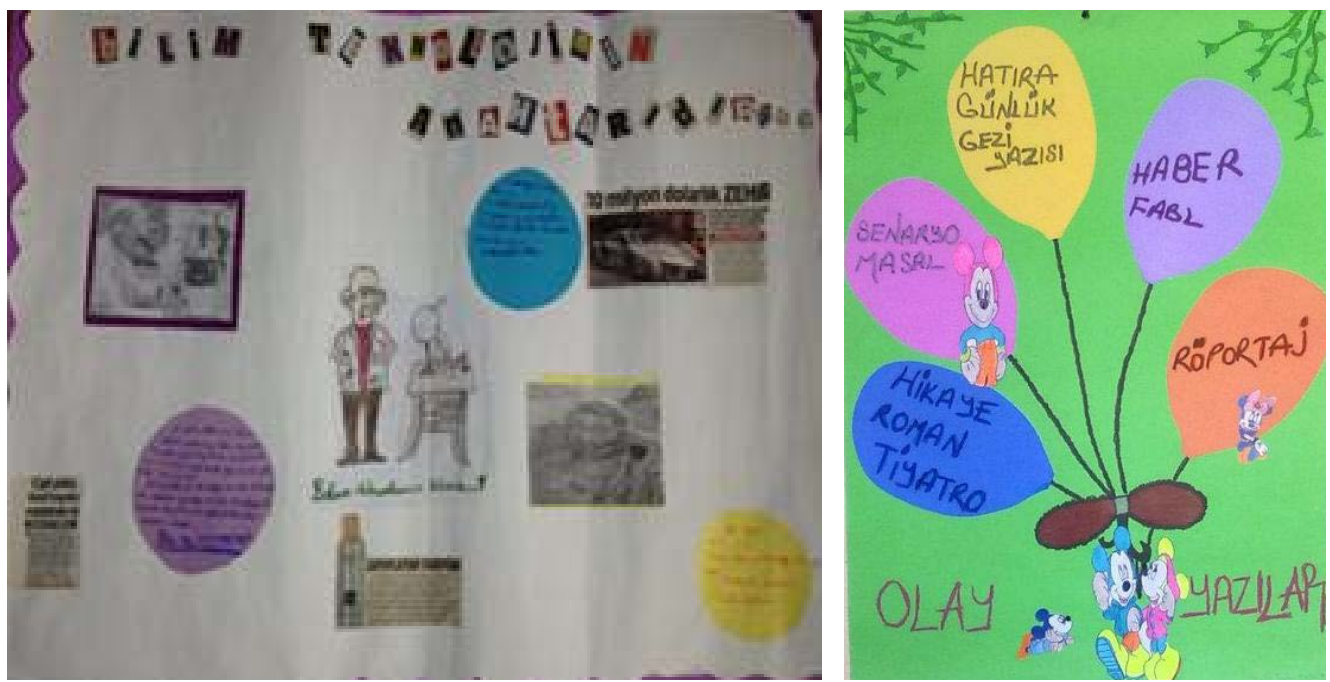

Fotoğraf 4. 6.sınıfta performans görevinin değerlendirilmesi (Görev/performans Hazırlama Süreci ve Görevin İçeriği) ile ilgili 20 ölçütün yer aldığı bilgisayar sayfası modülü $\left(\mathrm{D}_{13} / \ddot{O}_{13}\right)$

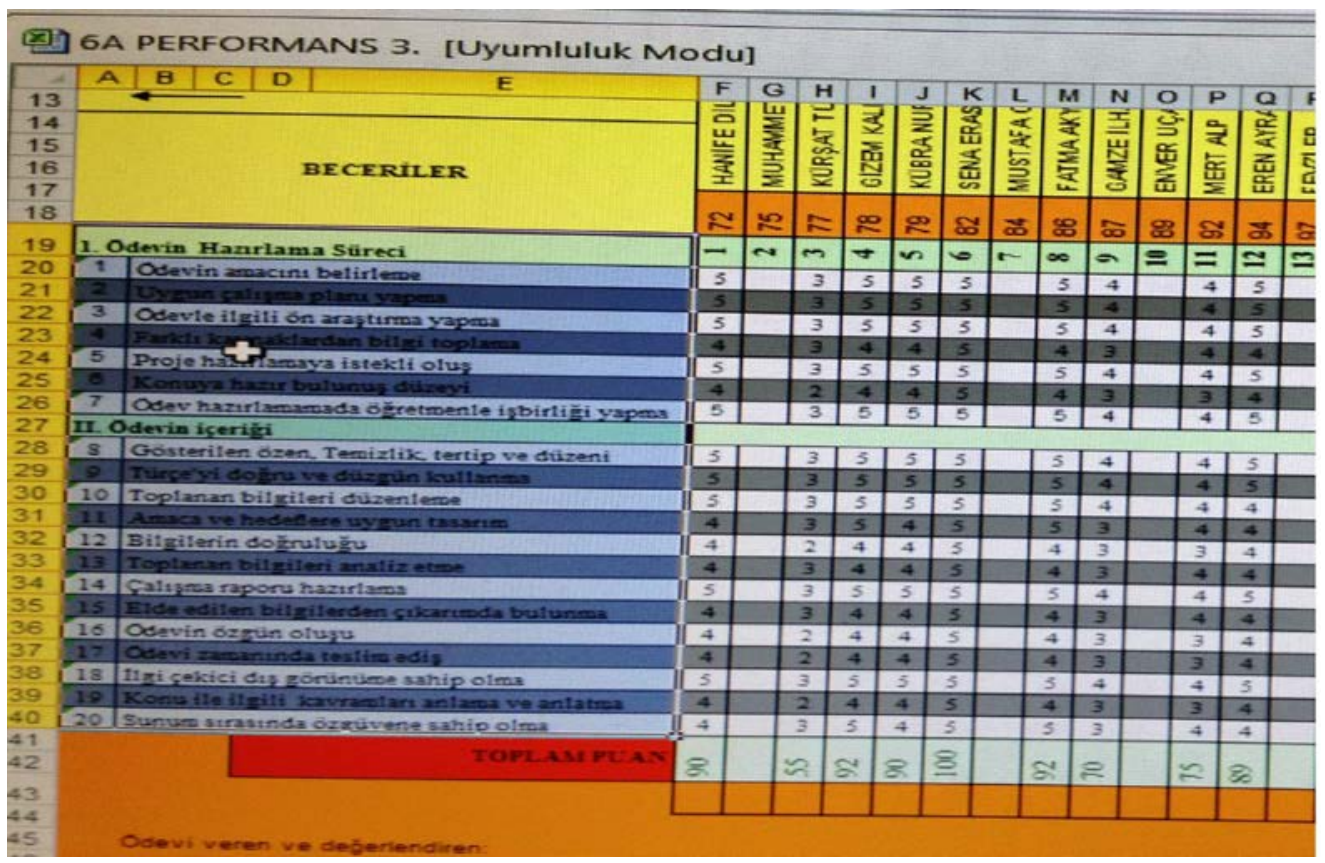

Foto $1\left(\mathrm{D}_{1,2}\right)$ ve Foto $2\left(\mathrm{D}_{3,4,5,6,7,8}\right)$ görsellerin tamamıla Foto 3 'teki $\mathrm{D}_{9}$ kod numaralı görsel dil bilgisi öğrenme alanına yönelik olarak verilen performans görevleriyle üretilen ürünleri göstermektedir. Foto 3'teki $\mathrm{D}_{10,11,12}$ kod numaralı görseller ise yazılı anlatım becerisinin geliştirilmesi amacıyla verilen performans görevleri ile üretilen ürünlerdir. Foto 4'te verilen bilgisayar sayfası modülü ise bir öğretmenin (Ö) dönem sonunda e-okul ders notu giriş modülünde değerlendirdiği performans görevlerine yönelik ölçütleri ve takdir ettiği notları göstermektedir. 
Uygulayıcı öğretmenlerden toplanan fotoğraflar arasından seçilerek araştırmada yer verilen fotoğraflara bakıldığında Türkçe öğretmenlerinin verdikleri performans görevlerinin dil bilgisi öğrenme alanına ait olduğu görülmektedir. Fotoğraflardan da görülebileceği gibi performans görevleri verilirken dil bilgisi öğrenme alanına ağırlık verildiği görülmektedir. Yapılan görüşmelerde öğretmenlerin verdikleri cevaplar düşünüldüğünde farklı tür ve konuda performans görevleri verdiklerine dair görüşleriyle verdikleri dokümanların çoğunluğunun dil bilgisi alanına yönelik olması dikkati çekmektedir. Görüşmeler sırasında zümre kararları gereğince öğrencilerin dil becerilerinin gelişimi ve ölçülmesine yönelik performans görevleri yanında öğrencilerin zihinsel ve sosyal becerilerinin de gelişimine yönelik görevlerin verildiği belirtilmişse de uygulamalara yönelik gözlemler ile verilen dokümanlara bakıldığında performans görevi çalışmalarında dil bilgisi alanına ağırlık verildiği görülmektedir.

\section{Sonuç ve Öneriler}

\section{Sonuçlar}

Türkçe öğretmenlerinin neredeyse tamamı bir eğitim-öğretim döneminde bir veya iki performans görevi vermekte; çalışmalarını amaç ve anlamına uygun yürüttüklerini düşünmektedirler.

Görüşüne başvurulan Türkçe öğretmenleri sınıf düzeyine bağlı olarak öğrencilerin üst düzey dilsel, zihinsel ve sosyal becerilerin geliştirilmesine yönelik farklı tür ve konuda performans görevleri verdiklerini söylemektedirler. Ancak öğrencilerden toplanan dokümanlar durumun hiç de öyle olmadığını göstermektedir. Çünkü öğrencilerin performans görevleri sonucu deyim albümü hazırlama, kitap özeti çıkarma, bir dil bilgisi konusuyla ilgili kavram haritası hazırlama vb. bilinen ürünleri ürettikleri görülmüştür. Oysa öğretmenler performans görevlerini belirlerken zümre kararları, ders kazanımları, kılavuz kitabı önerileri, program amaçları, çevre özellikleri, öğrenci ilgi, istek ve seviyeleri gibi değişkenleri göz önünde bulundurduklarını ifade etmişlerdir.

Türkçe öğretmenleri verdikleri performans görevlerinin değerlendirilmesinde amaca hizmet eden öğrenci merkezli alternatif ölçme ve değerlendirme araçları kullanmaktadırlar.

Türkçe öğretmenlerinin performans görevlerini bütünleyici çalışma çerçevesinde pekiştirme amacıyla kullandıklarını belirtmektedirler. Bu yolla yaparak yaşayarak öğrenmelere firsat oluşturulmakta ve araştırma, yaratıcılık, sorumluluk bilinci, özgüven duygusu, kendini ifade etme, analiz-sentez, etkileşim (etkili iletişim) vb. üst düzey beceriler geliştirilmeye çalışılmaktadır. Öğretmenler, bu tür performans görevleri ile öğrencilerin bilişsel, duyuşsal ve sosyal gelişimlerine katkısı açısından önemli işlevlere sahip olduğunu vurgulamaktadırlar.

Türkçe öğretmenlerinin verdiği performans görevleri şu konu ve alanlarda yoğunlaşmaktadır: 


\section{Sinif}

Deyim albümü hazırlayınız.

İstediğiniz bir yazarın romanını okuyarak sınıfta sunumunu yapınız?

Gördükleri dil bilgisi konusuyla ilgili resimli kavram haritası oluşturma, okudukları hikâyenin hikâye haritasının renkli fon kartlarına hazırlama, bilmecelerle ilgili oyun hazırlama.

Karagöz ve Hacivat oyunu (Tiplemelerin ve sahnenin yapılışı-sergilenmesi).

Yaratic1 fabl yazma.

Masal derleme ve birini anlatma.

Atatürk'ün anılarını derleme.

Yaratıcı masal yazma.

Atık maddelerden hayalindeki evi oluşturma.

Meslek Tanitımı

Güzel ülkem Türkiye temasında başta Karadeniz'deki iller olmak üzere il il tanıtım broşürleri hazırlama, kitap okuma saatlerindeki okuma performansları ve diğer görevlendirmeler,

Seçilen bir dil bilgisi konu, kavram veya kuralı ile ilgili bir afiş hazırlama.

Seçilen mesleği tanıtan bir rapor, dergi, sunu, poster veya broşür hazırlama...

6. Sinif

Atatürk'ün hayatından anıları derleyerek bir kitap oluşturma.

Noktalama işaretlerini anlatan bir hikâye oluşturunuz?

Fıkra yazıp canlandırma Karagöz-Hacivat oyunu canlandırma.

Çevrede görülen tabelalardaki dil hatalarını bulma.

Drama çalışmaları.

Hikâye derleme ve birini anlatma.

Deyim albümü hazırlama, metin türleri afişleri hazırlama.

Hikâye yazma, şair veya yazarların hayatlarının edebi yönlerinin araştırılması, roman özetleme.

Fon müziği eşliğinde ezbere şiir okuma, mektup yazma, hikâye yazıp resimleme, seçme şiir defteri oluşturma, anı canlandırma.

Günlük Oluşturma

Verilen metin içerisinde istenen ses olaylarının bulunması, verilen 5 kelime kullanılarak masal yazılması, şiir yazılması, karikatür çizilmesi.

Seçilen bir dil bilgisi konu, kavram veya kuralı ile ilgili bir afiş hazırlama.

TRT Çocuk Televizyonu'nda yayımlanan “Keloğlan Masalları” isimli çizgi filme hayalen bir bölüm yazma.

Yirmi gün süreli günlük tutma... 


\section{Sinif}

Atatürk hayatını anlatan bir anıyı grup oluşturarak canlandırma.

Okulumuzu tanıtacak bir afişs hazırlama.

Haber sunma, gazetedeki herhangi bir olayla ilgili sınıfta tartışma ortamı hazırlayıp görüş alış verişinde bulunma.

Drama, skeç canlandırma.

Fiillerle ilgili poster hazırlama.

Bir şairin hayatını anlatma ve bir şiirini ezberleme.

Türkçenin doğru kullanımıyla ilgili uyarı levhaları hazırlama, Atatürk'e ait özdeyişleri derleme.

Deyimlerin ve atasözlerinin çıkış noktalarının araştırılması, işlenilen temaya uygun pano hazırlama.

Fon müziği eşliğinde ezbere şiir okuma, mektup yazma, eser inceleme (seviyeye uygun romanlar), seçme şiir defteri oluşturma.

Atasözleri ve deyimleri oyunlaştırma, şair ve yazarlar afişi hazırlama.

Atasözleri, deyim ve vecize kutusu oluşturma.

Yaşam Öyküsü Andacı Hazırlama.

Düşünceyi Geliştirme Yolları Metinleri Oluşturma.

"Bilim adamı", "sporcu”, "ses sanatçısı", "film/tiyatro sanatçısı" ve "şair/yazar" olarak ün yapmış kişilerden birer kişi seçerek toplam beş ünlünün hayatlarını araştırma...

\section{Sinif}

Çevre kirliliği hakkında neler yapılabilir? Kendinizi belediye başkanının yerine koyarak çözüm önerisi üretiniz?

Türk destanlarından birini seçerek grup olarak sınıfta tanıtınız.

Bir hikâye yazma.

Şiir dinletisi, türkülerin çıkış kaynaklarını araştırma.

Bir kitabı okuyup tahlil etme.

Vatan şiirleri antolojisi hazırlama, noktalama işaretleri afişi hazırlama.

Roman yazma, şiir defteri oluşturma, sınıf dergisi hazırlama.

Eser inceleme (seviyeye uygun romanlar), Fon müziği eşliğinde ezbere şiir okuma, seçme şiir defteri oluşturma, dilbilgisi konuları ile ilgili tablolar hazırlama.

Düşünceyi geliştirme yolları ve anlatım biçimlerine birer örnek paragraf yazma.

Ünlü Türk Edebiyatçılarının hayatını araştırma.

Seçilen bir dil bilgisi konu, kavram veya kuralı ile ilgili bir afiş hazırlama.

Okul gazetesi hazırlama, çocuk dergisi hazırlama, şiir dinletisi hazırlama... 


\section{Öneriler}

Türkçe öğretmenleri performans görevi çalışmalarını öğrenme ve öğretme sürecinin önemli bir parçası olarak görmeli ve verdikleri eğitimle amaçlarına ulaşabilmeleri için bu uygulamanın tamamlayıcı işlevini göz ardı etmemelidirler.

Öğrencilerin bilişsel, duyuşsal ve sosyal gelişimlerine katkısı açısından önemli işlevlere sahip olan performans görevi çalışmalarının her sınıf düzeyinde faydalı bilgilerin edinilmesine ve farklı becerilerin gelişimine katkı sağlayacak şekilde uygulama çerçevesi geniş tutulmalıdır.

Performans görevlerinin öğrenci gelişimine olan katkısı kadar süreçte öğrenci gelişiminin ya da öğrenci performansının belirlenmesinde kullanılması gereken değerlendirme aracı olarak taşıdı̆̆ işlev unutulmamalıdır.

Sonuç olarak okullarda performans görevi çalışmaları hem ögrencilerin bilişsel, duyuşsal ve sosyal gelişimlerine zemin olan bir uygulama alanı hem de öğrenci gelişimi konusunda bilgi alınacak bir değerlendirme aracı olduğu bilinciyle hareket edilmelidir.

\section{Kaynakça}

Bahar, M., Nartgün, Z., Durmuş, S., \& Bıçak, B. (2006). Geleneksel-Alternatif Ölçme ve Değerlendirme. Ankara: Pegem A Yayıncılık.

Başol, G. (2013). Ĕgitimde Ölçme ve Değerlendirme (Genişletilmiş 2. Baskı). Ankara: Pegem Akademi.

Berberoğlu, G. (2006). Sınıf İçi Ölçme ve Değerlendirme Teknikleri. İstanbul: MORPA kültür Yayınları.

Birgin, O. \& Küçük, M. (2012). Alternatif Ölçme-Değerlendirme Araç ve Yöntemleri (ss. 159-203), Ĕ̌itimde Ölçme ve Değerlendirme (Editörler: Küçük, M. \& Geçit, Y.). Ankara: Nobel Akademik Yayıncılık.

Büyüköztürk, Ş., Çakmak, E., Akgün, Ö., Karadeniz, Ş., \& Demirel, F. (2009). Bilimsel Araştırma Yöntemleri (4. Bask1). Ankara: Pegem Akademi.

Ekiz, D. (2009). Bilimsel Araştırma Yöntemleri (2. Baskı). Ankara: Anı Yayıncılık.

Ekiz, D., Erdoğan, T. \& Uzuner, F. G. (2011). Okuma Güçlüğü Olan Bir Öğrencinin Okuma Becerisinin Geliştirilmesine Yönelik Bir Aksiyon Araştırması. ABÜ Ĕgitim Fakültesi Dergisi, 11(2), 111-131.

Göçer, A. (2008). Performans Görevleriyle İlgili Sunum Çalışmalarının Konuşma ve Dinleme Becerilerinin Geliştirilmesine Katkısı. Dil Dergisi, 142, 7-17.

Göçer, A. (2013). Türkçenin Yabanc1 Dil Olarak Öğretiminde Görevlendirilecek Öğretim Elemanlarının Göreve Hazır Bulunuşluk Durumlarının Değerlendirilmesi. The Journal of Academic Social Science Studies, 6(5), 309-326.

Günel, E. (2012). Nitel Araştırmayla Tanışma (ss. 1-36), Nitel Araştırmaya Giriş (Carrine Glesne, Çev. Editörleri: Ersoy, A. \& Yalçınoğlu, P.). Ankara: Anı Yayınc1lık. 
Köklü, N. (1993). Eylem Araştırması. AÜ Eğitim Bilimleri Fakültesi Dergisi, 26(2), 357-365.

Kutlu, Ö., Doğan, C. D. \& Karakaya, İ. (2008). Öğrenci Başarısının Belirlenmesi. Ankara: Pegem Akademi.

Kuzu, A. (2009). Öğretmen Yetiştirme ve Mesleki Gelişimde Eylem Araştırması. Uluslararası Sosyal Araştırmalar Dergisi, 2(6),425-433.

MEB (2006), İlkögretim Türkçe Dersi (6, 7 ve 8.Sınıflar) Öğretim Programı. Ankara: Talim ve Terbiye Kurulu Başkanlığı Yayını.

Punch, K. F. (2005). Sosyal Araştırmalara Giriş: Nitel ve Nicel Yaklaşımlar (Çev.: D. Bayrak, B. Aslan \& Z. Akyüz), Ankara: Siyasal Kitabevi.

Tok, Ş. (2007). Öğretme - Öğrenme Strateji ve Modelleri (ss. 129-159), Öğretim İlke ve Yöntemleri (Editör: Doğanay, A.). Ankara: Pegem A Yayıncılık.

Yıldırım, A. \& Şimşek, H. (2005). Sosyal Bilimlerde Nitel Araştırma Yöntemleri (5. Baskı). Ankara: Seçkin Yayıncılık. 